\title{
Seasonality of Mansonia titillans during dam construction, Biritiba-Mirim, São Paulo State, Brazil
}

\author{
Frederico Alves D'Avila ${ }^{1,2}$ \& Almério de Castro Gomest' (in memorian) \\ ${ }^{1}$ Departamento de Epidemiologia, Faculdade de Saúde Pública, Universidade de São Paulo - USP, \\ CEP 01246-904, São Paulo, SP, Brasil \\ ${ }^{2}$ Corresponding author: Frederico Alves D'Avila, e-mail: frdavila@ib.usp.br
}

D'AVILA, F.A. \& GOMES, A.C. Seasonality of Mansonia titillans during dam construction, BiritibaMirim, São Paulo State, Brazil. Biota Neotrop. 13(1): http://www.biotaneotropica.org.br/v13n1/en/ abstract?article+bn01213012013

\begin{abstract}
A two and a half year survey was conducted at a dam in southeastern Brazil. Shannon Traps were used for sampling. Kruskal-Wallis test showed little relation between rainfall and abundance. The data clearly show three abundance peaks, all of them in the end of the dry season, in consonance with the scarce literature existent. Although Kruskal-Wallis Test did not find a clear preference for the dry season, Pairwise Wilcoxon Rank Test revealed a significant difference between Fall and Spring samples. Ma. titillans population had a peak on late winter/early spring, close to the begin of wet season.
\end{abstract}

Keywords: mansoniini, insect vector, artificial lake.

D’AVILA, F.A. \& GOMES, A. C. Sazonalidade de Mansonia titillans durante a construção de uma represa, Biritiba-Mirim, Estado de São Paulo, Brasil. Biota Neotrop. 13(1): http://www.biotaneotropica.org.br/v13n1/ pt/abstract?article+bn01213012013

Resumo: Uma pesquisa de dois anos e meio foi realizada em uma represa no sudeste do Brasil. Foram utilizadas Armadilhas de Shannon para coleta. O teste Kruskal-Wallis mostrou pouca correlação entre a precipitação e abundância. Os dados mostram claramente três picos de abundância, todos eles no final da estação seca, em consonância com a escassa literatura existente. Apesar do teste de Kruskal-Wallis não ter encontrado uma clara preferência pela estação seca, o Teste de Wilcoxon par-a-par revelou uma diferença significativa entre as amostras do Outono e da Primavera. A população de Ma titillans tem um pico no fim do inverno/início da primavera, próximo ao início da estação chuvosa.

Palavra-chave: mansoniini, inseto vetor, lago artificial. 


\section{Introduction}

Culicidae is one of the most studied insect family. Since late $19^{\text {th }}$ century, when its role on yellow fever transmission (Franco 1969) was discovered. Since than many others illness were attributed as mosquito-borne, such as malaria, filariasis, and most of the caused by arboviruses.

Mansonia titillans (Walker 1848) is widely distributed in the Americas, occurring in tropical and subtropical Western Hemisphere from Southern USA to Argentine, including Caribbean Islands (Walter... 2011). It has some medical importance, as an irritating nuisance and as possible vector of Venezuelan Equine Encephalitis, which may cause sudden death and/or central nervous system disorder in these animals and also humans (Carpenter \& La Casse 1955, Méndez 2001).

Mansoniini tribe has, while immatures, an unique breathing form. After hatching, the larvae attach their siphons, and themselves, to submerged roots of aquatic plants, obtaining oxygen from its aerenchymas. The pupae also remain attached to the roots of the plants until time for emergence of the adults. Water lettuce (Pistia stratiotes L.) and water hyacinth (Eichornia crassipes Kinth) are the principal host plant (Harbach 2011). Due to this specificity, Mansoniini species are quite dominant where aquatic plants are abundant, normally eutrophized lakes and lagoons, frequently artificials.

Although its abundance, studies on Ma.titillans abundance and seasonality are scarce. This study describes the population fluctuation of this mosquito in artificial dam surroundings, near a metropolis in southeastern Brazil.

\section{Materials and Methods}

A 32-month survey was conducted from May 2002 to December 2004 at Biritiba-Mirim Dam (23 31' 74" S and 45 57" 14 " W), in construction at the time, as part of its environmental impact analysis. At homonymous city and river, this dam is part of a water provision and flood control complex, Producer System of High Tietê (SPAT, in portuguese), in the 'Rio Tietê', about $70 \mathrm{~km}$ east from São Paulo city. It is a tropical region characterized by seasonal flooding, with a well defined rainfall season from November to March, accounting more than $60 \%$ of the total annual rainfall of about $1,400 \mathrm{~mm}$, and a dry season from April to October. Average annual temperature is $25.9^{\circ} \mathrm{C}$ (Centro... 2011).

Native vegetation on High Tietê Basin is majorly 'Mata Atlântica' rainforest. At the dam surrounding is common to find a mosaic of native vegetation and human activities, such as agriculture, loam and sand mines and eucalyptus reforestation (Centro..., 2001).

Mosquito catches were realized monthly, in a forest fragment near the construction site. Captures were carried out with Shannon Traps (Shannon 1939), gas-lamp lighted, two men operated, during the first 4 hours after dusk. Cloroform-filled deadly tubes were used to capture each specimen, it was then stored in labeled entomological boxes and carried to 'Laboratório de Entomologia em Saúde Pública (LESP) - FSP/USP'. All specimen were indentified according to Forattini key (2002).

Monthly records of rainfall were obtained from a weather station near the study site. Statistical analysis was performed using data from monthly catches and climatic data through Spearman's Rank Correlation Coefficient, Pairwise Wilcoxon Rank Sum Test and Kruskal-Wallis H tests (Lowry 2012, Sachs 1992, Siegel \& Castellan 1988, Spearman 1904), non-parametric, to evaluate the significance level of seasonal differences in insect abundance, and assess the influence of climatic parameters on population dynamics. ShapiroWilk Test (Shapiro \& Wilk 1965) was used for normality test. All analysis was performed using R Statistical Computing Environment.

\section{Results}

A total of 8,783 Culicidae were caught during the study period. Mansoniini totalized 4,098 specimens, from the following species: Coquillettidia albicosta Peryassui 1908, Coquillettidia chrysonotum Peryassui 1922, Coquillettidia hermanoi Lane \& Hermanoi 1940, Coquillettidia juxtamansonia Chagas 1907, Coquillettidia venezuelensis Theobald 1912, Mansonia flaveola Coquillett 1905, Mansonia indubitans Dyar \& Shannon 1925 and Mansonia titillans Walker 1848.

Ma. titillans $(\mathrm{n}=2,401)$ was $27.3 \%$ of all culicideans and $58.8 \%$ of Mansoniini. Its abundance was equally important among the capture sites. Ma. titillans females $(98,4 \%)$ were more frequently seen than males in the traps.

Interspecific competition with Coquillettidia and other Mansonia species did not play a major role in this study, since relative abundance of all species of this genus was consistently lower then Ma. titillans during the two and a half years studied.

The weather was typical for the region during the studied period. The dry season take place between late fall and early spring, during 4 months, with some period variation. Rainy season began in September-October, and the heaviest rainfall period was from December to February (Figure 1).

Three population peaks were recorded (Figure 2), all of them occurred in September [2002] or October [2003/2004], coinciding with the end of the dry season and beginning of the wet one at this region.

First of all, the normality of the samples distribution was tested through Shapiro-Wilk Test and, as expected, normality of the sample was rejected $(\mathrm{p}<0.001, \mathrm{~W}=0,67)$

The Kruskal-Wallis Test was performed to search for preference among the seasons. The null hypothesis, that the samples from different seasons have the same median, was accepted $(H=7.6779$, $\mathrm{p}=0.05316, \mathrm{df}=3$ ), indicating that the seasonality of Ma. titillans was not directly determined by rainfall.

Spearman's rank correlation coefficient showed little correlation between rainfall and Ma. titillans abundance $(\rho=0.173)$, and also was little when compared Other Mansoninii with rainfall $(\rho=0.008)$ and Ma. titilans and other Mansoninii abundance $(\rho=0.017)$.

On Pairwise Wilcoxon Rank Sum Test, a significant difference was found between the Fall and Spring samples (0.049), while all other comparisons were non-significant.

\section{Discussion}

Although statistical insignificance, Kruskal-Wallis' p-value was placed at the boundary of $\mathrm{H}_{0}$ acceptance. This data is complemented by Pairwise Wilcoxon, which had significant difference. The combination of both tests can be interpreted by Ma. titillans having a relative stable abundance along the year, with one peaks of great abundance. So is clear that there are cyclical peaks of abundance, somehow related to the seasons of the year.

The statistical analysis of the data did not reveal a connection between abundance and rainfall; this result can be explained by its ecology. Ma. titillans immature stages live on permanent breeding sites, which abundance and quality are not directly dependent of rainfall allowing $M a$. titillans to be abundant throughout the year. An explanation on abundance peaks can be its breathing technique; using aerenchymas allow Mansoniini, and Ma. titillans specifically, to find they optimum environment, while others, lwhen also living on eutrophized waters, find hard times during dry season. De Kruijf (1975) also registered an abundance peak at similar season. 


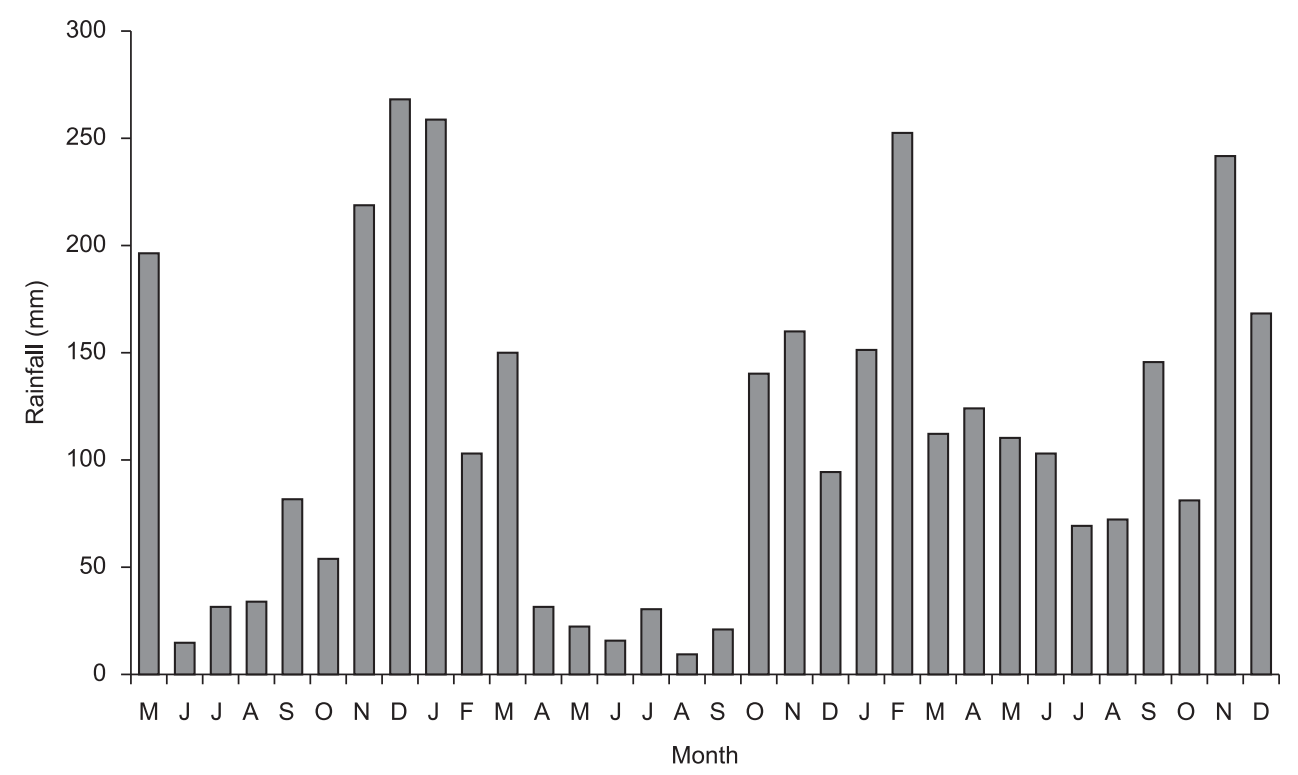

Figure 1. Rainfall data in the Biritiba-Mirim Dam, State of São Paulo, Brazil, May 2002 to December 2004.

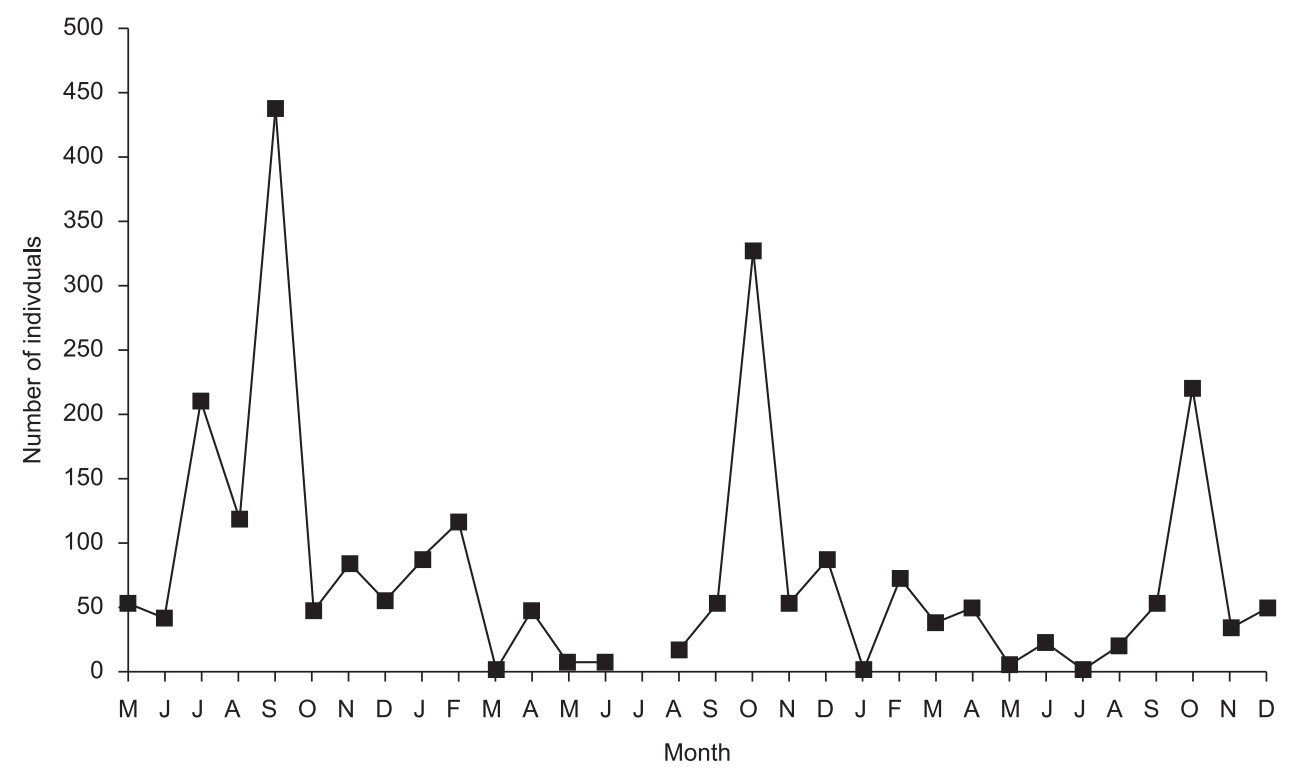

Figure 2. Seasonal fluctuation of Mansonia titillans in the Biritiba-Mirim Dam, State of São Paulo, Brazil, May 2002 to December 2004.

Ma. titillans is dependent of aquatic plants, which are normally perennial, so dry season may be when interspecific competition is less important and less strong.

Remarkable differences have been described regarding abundance of Ma. titillans in modified and primeval areas, while Taddei (1996) found relative frequency of 94\%, studies in other 'Mata Atlântica' areas found much lower abundances (Guimarães et al. 2004, Reis et al. 2010, Forattini et al. 1986). This data indicates that Ma. titillans is a species mainly found in man-made environment, bringing, commonly, nuisance more than bearable to man and cattle, like in Tucuruí.

In conclusion, when living in optimum environment, Ma. titillans shows a behavior with population peak in late winter/early spring, close to the begin of wet season.

\section{Acknowledgements}

We thank CNPq for the financial support that made this research possible, EMAE for supporting the research and offering all needed infrastructure. The biologists Márcia Bicudo de Paula, Paulo Roberto Urbinatti, Delsio Natal, Aristides Fernandes, Marcelo Sciarreta for identification and capture help.

\section{References}

CARPENTER, S.J. \& LA CASSE, W.J. 1955. Mosquitoes of North America (north of Mexico). Univ. of Calif. Press, Berkeley, Los Angeles, p.360.

CENTRO DE MONITORAMENTO AMBIENTAL DA SERRA DO ITAPETI - CEMASI. 2001. Biodiversidade nas Bacias do Rio Paraitinga e do Rio Biritba-Mirim. SERH/DAEE/CEMASI, São Paulo. Relatório Técnico 
CENTRO DE PESQUISAS METEOROLÓGICAS E CLIMÁTICAS APLICADAS À AGRICULTURA - CEPAGRI. Clima dos Municípios Paulistas. Clima de Biritiba-Mirim. http://www.cpa.unicamp.br/outrasinformacoes/clima_muni_075.html (último acesso em 15/12/2011).

DE KRUIJF, H.A.M. 1975. The relations beetween rainfall and mosquito populations In Tropical Ecological Systems. Trends in Terrestrial and Aquatic Research (F.B. Golley \& E. Medica, eds). Ecological Studies, n.11, p.62-65.

FORATTINI, O.P. 2002. Culicidologia Médica v.2. EdUSP, São Paulo.

FORATTINI, O.P., ALVES, A.C., NATAL, D. \& SANTOS, J.L.F. 1986. Observações sobre atividade de mosquitos Culicidae em mata primitiva da encosta no Vale do Ribeira, São Paulo, Brasil. Rev. Saude Publ. 20(1):120. http://dx.doi.org/10.1590/S0034-89101986000100001

FRANCO, O. 1969. História da febre amarela no Brasil. Rev. Bras. Malariol. Doenças Trop. 21: 315-520. PMid:4906976.

GUIMARÃES, A.E., LOPES C.A., MELLO R.P. \& ALENCAR J. 2000. Ecologia de mosquitos (Diptera: Culicidae) em áreas do Parque Nacional da Serra da Bocaina, Brasil. 1 - Distribuição por habitat. Cad. Saude Publica 34(3):1107-1116 .

HARBACH, R.E. 2011. Tribe Mansoniini. Mosquito Taxonomic Inventory. http://mosquito-taxonomic-inventory.info/tribe-mansoniini-belkin-1962 (último acesso em 16/12/2011).

LOWRY, R. 2012. Concepts and Applications of Inferential Statistics. http:// vassarstats.net/textbook/ch12a.html (último acesso em 22/04/2012)
MÉNDEZ, W., LIRIA, J., NAVARRO, J.-C., GARCIÁ, C.Z., FREIER, J.E., SALAS, R., WEAVER, S.C. \& BARRERA, R. 2001. Spatial Dispersion of Adult Mosquitoes (Diptera: Culicidae) in a Sylvatic Focus of Venezuelan Equine Encephalitis Virus. J. Med. Entomol. 38(6): 813-819. PMid:11761379. http://dx.doi.org/10.1603/0022-2585-38.6.813

REIS, M., AZULIM, G.M. \& MARCONDES, C.B. 2010. Inventário de mosquitos (Diptera: Culicidae) da Unidade de Conservação Ambiental Desterro, Ilha de Santa Catarina, Sul do Brasil. Biota Neotrop. 10(3) http://www.biotaneotropica.org.br/v10n3/pt/abstract?inventory+ bn01610032010 (último acesso em 05/12/2011).

SHANNON, R. 1939. Methods for collecting and feeding mosquitoes in jungle yellow fever studies. Am. J. Trop. Med. Hyg. 19:131-140.

SHAPIRO, S.S. \& WILK, M.B. 1965. An analysis of variance test for normality (complete samples). Biometrika 52(3/4):591-611. http://dx.doi. org/10.2307/2333709

SIEGEL, S. \& CASTELLAN, JRNJ. 1988. Nonparametric Statistics for the Behavioral Sciences. 2. ed. McGraw-Hill, New York.

SPEARMAN, C. 1904. The proof and measurement of association between two things. Amer. J. Psychol. 15(1):72-101. http://dx.doi. org/10.2307/1412159

TADDEI, W.P. 1996. O gênero Mansonia (Diptera: Culicidae) e a proliferação de mosquitos na usina hidrelétrica de Tucuruí. In Energia na Amazônia (S.B. Magalhães, R.C. Brito \& Castro E.R., eds). MPEG/FPA/UNAMAZ, Belém, v.1, p.311-318

WALTER REED BIOSSYSTEMATICS UNIT. Systematic Catalog of Culicidae. http://mosquitocatalog.org/taxon_descr.aspx?ID=40 (último acesso em 13/12/2011). 